\title{
Eosin Y Promoted C-H Arylation of Heteroarenes with Aryl Diazonium Salts
}

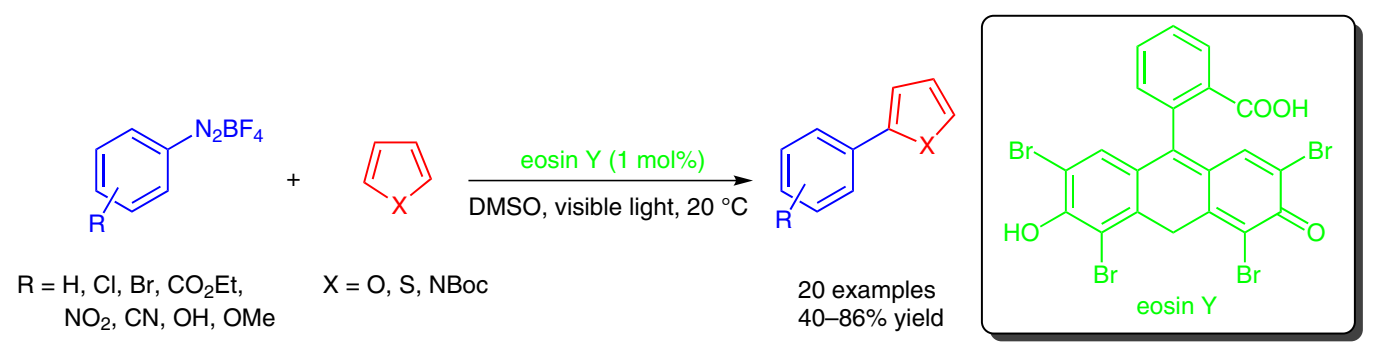

Selected examples:<smiles>c1ccc(-c2ccco2)cc1</smiles>

$60 \%$ yield<smiles>O=[N+]([O-])c1ccc(-c2cccs2)cc1</smiles>

$70 \%$ yield<smiles>Clc1ccc(-c2ccco2)cc1</smiles>

$74 \%$ yield<smiles>CC(C)(C)OC(=O)n1cccc1-c1ccc([N+](=O)[O-])cc1</smiles>

$61 \%$ yield<smiles>O=[N+]([O-])c1ccc(-c2ccco2)cc1</smiles>

$85 \%$ yield<smiles>CCOC(=O)c1ccc(-c2cccn2C(=O)OCc2ccccc2)cc1</smiles>

$51 \%$ yield

Mechanistic study:<smiles>CCN(c1ccc([N+](=O)[O-])cc1)C(F)(F)F</smiles><smiles>CON1C(C)(C)CCCC1(C)C</smiles>

$\underset{\text { DMSO, visible light }}{\stackrel{\operatorname{eosin} Y(1 \mathrm{~mol} \%)}{\longrightarrow}}$<smiles>CC1(C)CCCC(C)(C)N1OC1C=COC1c1ccc([N+](=O)[O-])cc1</smiles>

detected by mass spectroscopy

Significance: König and co-workers have developed a metal-free, direct intermolecular C-H arylation of heteroarenes with aryl diazonium salts by photoredox catalysis with green light. The reaction proceeds smoothly at room temperature, does not require transition-metal catalysts or bases, and displays a broad scope toward diazonium salts and heterocycles with a wide range of functional group tolerance. A suggested radical mechanism has been proposed based on experimental observations and literature data.
Comment: Arylated heteroarenes are widely used in materials science because of their interesting optical and electronic properties, but also in biomedical applications as peptide mimetics or drugs. Herein, the authors report a metal-free, direct intermolecular $\mathrm{C}-\mathrm{H}$ arylation of heteroarenes with aryl diazonium salts by photoredox catalysis with green light. This single-electron transfer crosscoupling represents an efficient alternative to known transition-metal-catalyzed methods and may find applications beyond synthesis, such as in the chemical patterning of surfaces.

SYNFACTS Contributors: Benjamin List, Qinggang Wang

Dol: 10.1055/s-0031-1290582; Reg-No.: B02012SF 